\title{
Sir Colin Mackenzie, M.D., F.R.C.S.Ed.
}

Colin Mackenzie was born of Scottish parents at Kilmore, Victoria, in 1877 . One of four brothers educated for the medical profession, he graduated M.B. at the University of Melbourne in 1898 and M.D. in I9OI. In the early years of his professional life he had experience of general practice, but the lines of his career were soon determined by teaching appointments in Anatomy at the University of Melbourne and a clinical appointment at the Children's Hospital in that city.

In 1904 he visited Europe to pursue orthopædic studies, and worked for some time with Robert Jones at Liverpool. Faced with a severe epidemic of infantile paralysis soon after his return to Melbourne, he devised new methods of treatment for the immediate and remote effects of that crippling malady.

Success in specialist orthopædic practice followed, but meanwhile Mackenzie had taken up an intensive study of the comparative anatomy of the peculiar fauna of Australia from the point of view of the correlation of structure and function. To this work he devoted all his spare time and began to build up a great collection of dissections.

During the War he worked in London, and was for a time actively associated with the treatment of war injuries, in charge of a special department in the Military Orthopædic Hospital at Shepherd's Bush.

Thereafter Mackenzie devoted himself finally to the comparative anatomy of the Australian fauna, and in 1924 the dream which had inspired him for many years was realised. In that year he presented to the Federal Government his great private collection of specimens and dissections, and a special Act was passed establishing the Australian Institute of Anatomy. He was appointed the first Director and in 1930 his collection, now greatly augmented by the addition of anthropological and other material, was transferred to the monumental building which had been erected to receive it. It will assuredly be a lasting memorial to Mackenzie's vision, industry and tenacity of purpose.

His well-known book on The Action of Muscles, including Muscle Rest and Re-education was published in 1918; Intellectual Development and the Erect Posture followed in 1924; and he also recorded his observa- 
tions on the Comparative Anatomy of the Australian Fauna in four volumes.

$\mathrm{He}$ received the honour of Knighthood in 1929. He had been President of the Royal Zoological Society of Victoria, and in 1928 was Bancroft Lecturer and President of the Zoological Section of the Australian Science Congress. In 1937 he was elected the first President of the Royal Society of Australia.

Sir Colin Mackenzie died in Australia on June 29, 1938, a few months after he had resigned his post of Director of the Institute of Anatomy on account of ill-health. He was elected a Fellow of this Society in 1905.

J. C. B. 